\title{
The use of polymethyl-methacrylate (Artecoll) as an adjunct to facial reconstruction
}

\author{
David Mok BSc, Jorge Schwarz BSc MD FRCS(C) FACS
}

D Mok, J Schwarz. The use of polymethyl-methacrylate (Artecoll) as an adjunct to facial reconstruction. Can J Plast Surg 2004;12(1):39-42.

BACKGROUND: Injectable polymethyl-methacrylate (PMMA) microspheres, or Artecoll, has been used for the last few years in aesthetic surgery as long-term tissue filler for the correction of wrinkles and for lip augmentation. This paper presents three cases of the use of PMMA microsphere injection for reconstructive patients with defects of varying etiologies. These cases provide examples of a novel adjunct to the repertoire of the reconstructive surgeon.

OBJECTIVES: To evaluate the effectiveness (short- and long-term) of PMMA injection for the correction of small soft tissue defects of the face.

METHODS: Three case histories are presented. They include the origin of the defect; previous reconstructions of the defect; and area, volume, timing and technical particularities of PMMA administration.

RESULTS: All three cases showed improvement of the defect with the PMMA injection with respect to both objective evidence and patient satisfaction. The improvements can still be seen after several years.

CONCLUSIONS: PMMA microsphere injection can be effectively used to correct selected small facial defects in reconstructive cases and the results are long lasting.

Key Words: Artecoll; Microspheres; Polymethyl-methacrylate; Soft tissue reconstruction

\section{Le recours au polyméthacrylate de méthyle (Artecoll) comme traitement d'appoint de la reconstruction faciale}

HISTORIQUE : Des microsphères de polyméthacrylate de méthyle (PMMA), ou Artecoll, sont utilisées en chirurgie esthétique depuis quelques années à titre de charge tissulaire pour corriger les rides ou grossir les lèvres. Le présent article présente trois cas de recours à l'injection de microsphères de PMMA pour des patients subissant une reconstruction et présentant des anomalies d'étiologies diverses. Ces cas fournissent des exemples de traitement d'appoint à ajouter au répertoire du chirurgien reconstructif.

OBJECTIF : Évaluer l'efficacité (à court et à long terme) d'une injection de PMMA pour corriger des anomalies de petits tissus mous de la face. MÉTHODOLOGIE : Trois histoires de cas sont présentées. Elles incluent l'origine de l'anomalie, les reconstructions précédentes de l'anomalie ainsi que le foyer, le volume, le moment et les particularités techniques de l'administration de PMMA.

RÉSULTATS : Les trois cas ont profité d'une diminution de l'anomalie après l'injection de PMMA, tant pour ce qui est des données objectives que de la satisfaction du patient. Ces diminutions s'observent encore plusieurs années plus tard.

CONCLUSIONS : L'injection de microsphères de PMMA peut être utilisée avec efficacité pour corriger de petites anomalies faciales sélectionnées dans des cas de reconstruction, et les résultats sont durables.

\begin{abstract}
A rtecoll is a synthetic fillant consisting of polymethylmethacrylate (PMMA) microspheres that is used as an aesthetic product to correct facial wrinkles and to augment labial tissue $(1,2)$. It is injected in the lower third of the dermis at a specific depth. PMMA demonstrates a good track record for biocompatibility, although foreign body reactions have been reported (3-5). What makes PMMA microspheres unique in comparison with other soft tissue fillants is that it is not resorbed and provides a long-lasting correction of approximately five years (6).

While aesthetic corrections of lines and folds in healthy, normal skin can be accomplished with the use of PMMA injections, it has yet to be reported in reconstructive cases. Reconstructive surgeons are faced with abnormal anatomy, scar tissue, fibrosis and abnormal planes between dermis and subdermal tissue. The use of PMMA as a reconstructive
\end{abstract}

material is challenging, because PMMA beads must be positioned in a specific depth: superficially enough to have a visible effect on skin contours, but deep enough not to be palpable. As well, fibrotic tissue may present technical difficulties to the surgeon because they may be injecting against a greater resistance through the dense collagen fibres. Finally, the long-lasting results seen with PMMA use in normal skin may not cross-over to damaged and/or abnormal tissue.

\section{Case 1}

\section{CASE PRESENTATIONS}

A 70-year-old white woman, with a soft tissue defect in the right upper lip secondary to trauma, presented to the clinic for information on corrective options. When she was first seen in the clinic, she had no previous reconstructive attempts (Figure 1A). 


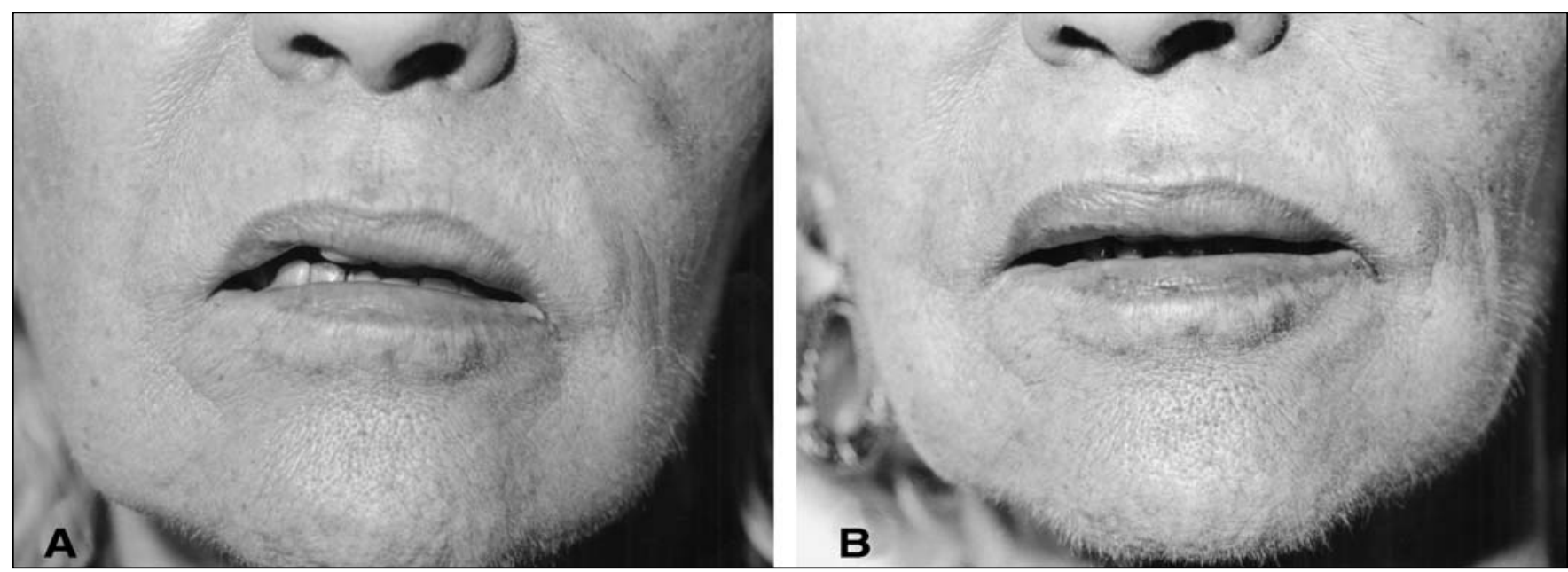

Figure 1) A A 70-year-old white woman, with a soft tissue defect in the right upper lip secondary to trauma. B After $0.3 \mathrm{~mL}$ plus $0.2 \mathrm{~mL}$ of polymethyl-methacrylate microspheres injected at the wet-dry junction of the red lip

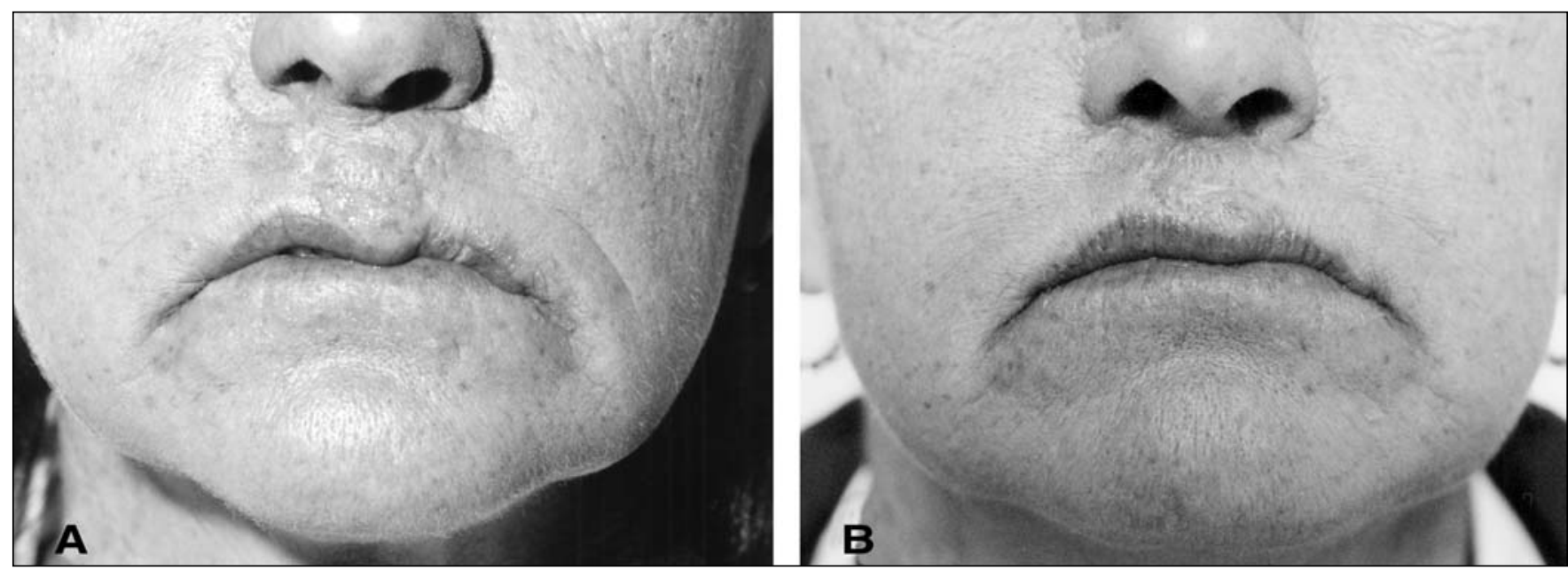

Figure 2) A A 51-year-old woman with an upper lip deformity secondary to a congenital hemangioma after multiple surgical corrections. B After multiple polymethyl-methacrylate microsphere injections at the vermillion border with a total volume of $2.2 \mathrm{~mL}$

She initially received a $0.3 \mathrm{~mL}$ injection of the PMMA product. It was injected in the area of the red lip at the wet-dry junction. The defect was partially corrected with the initial injection and produced no adverse reactions. A second stage procedure was done where a $0.2 \mathrm{~mL}$ injection of PMMA was added over the same area.

The soft tissue defect was adequately filled (Figure 1B). Three years postinjection, the defect is still well corrected and the patient is highly satisfied with the outcome.

\section{Case 2}

A 51-year-old white woman presented with an upper lip deformity secondary to a congenital hemangioma. She had already undergone multiple surgical reconstructions (Figure 2A).

Over a period of six months, the patient received multiple injections of PMMA, totalling $2.2 \mathrm{~mL}$. The product was infiltrated at the vermillion border with a significant amount directly injected into scar tissue. After each injection, the skin was thoroughly massaged for several minutes to evenly distribute the infiltrate. The patient had no adverse reactions.

Objectively, the procedure corrected the defect adequately, although not completely (Figure 2B). Two years after the procedure, the correction remains. The patient has maintained a moderate degree of satisfaction.

\section{Case 3}

A 39-year-old white woman with a previously corrected cleft lip and nasal deformity presented to the clinic. The patient underwent a midline Abbe flap to add volume and correct a defect in her upper lip 10 years ago. The procedure provided some improvement; however, the patient was left with two 


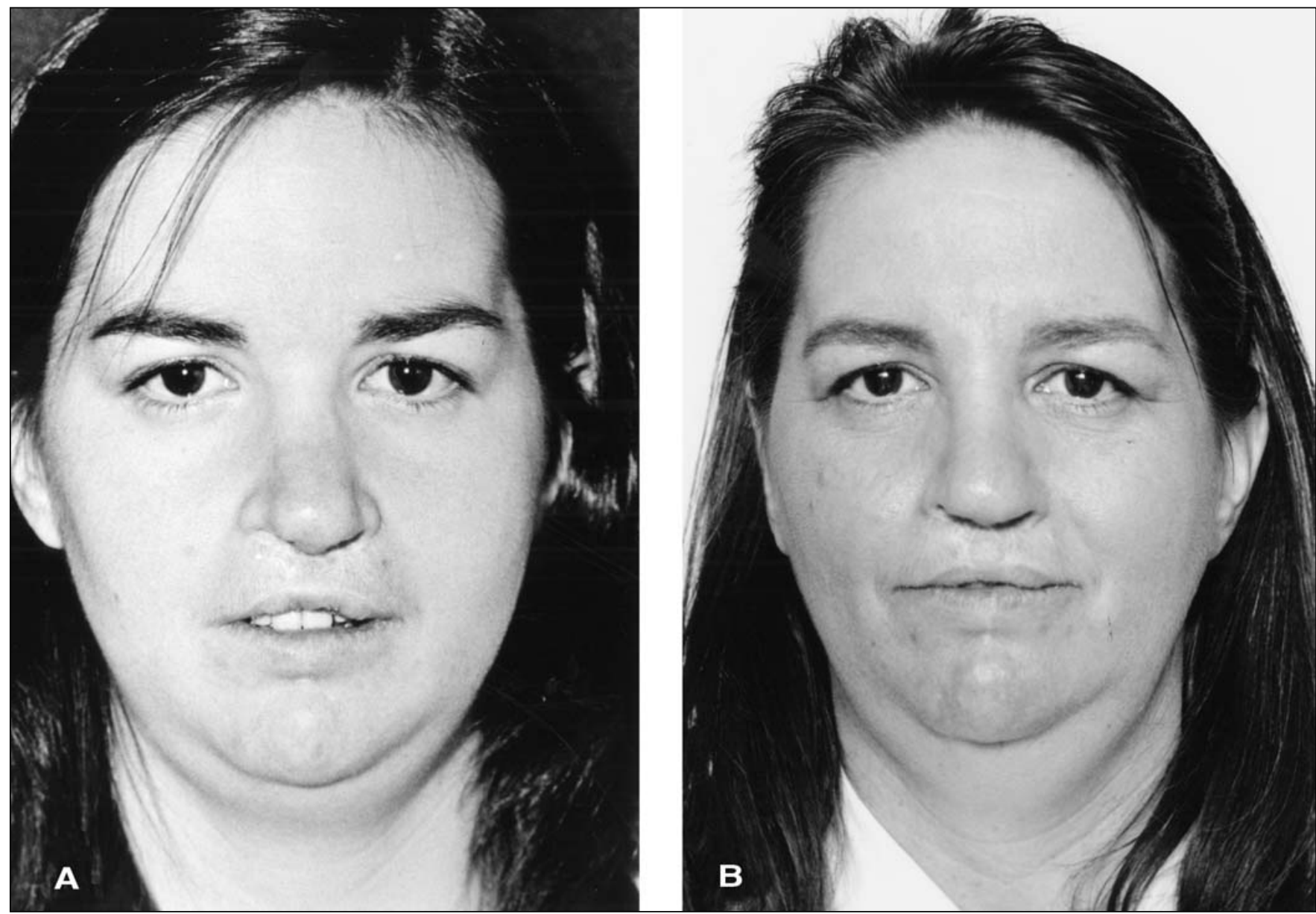

Figure 3) A A 39-year-old white woman with a previous cleft lip corrected with an Abbe flap. Note the two indentations of the red lip below the philtral columns. B After $1.0 \mathrm{~mL}$ of polymethyl-methacrylate microspheres infiltrated directly into the scar tissue at the indentations of the red lip

indented, contracted scars lateral to her philtral columns down to her red lip (Figure 3A).

Six years later, $1.0 \mathrm{~mL}$ of PMMA was infiltrated directly into the scar tissue at the point of indentations of the red lip. As it was injected directly into the scar, it was injected against a strong resistance and was aggressively massaged for a prolonged period of time.

The PMMA injection partially corrected the bilateral indentations and added more volume to the patient's contracted upper lip (Figure 3B). The patient had no adverse reactions. At four years postcorrection the defects have not reappeared. The patient was satisfied with the procedure.

\section{DISCUSSION}

These cases present the use of PMMA microsphere injections for nonaesthetic purposes. The corrections to the defects in the above examples have significant differences to the normal usage of PMMA injections. Greater volumes of the product were needed to fill larger defects. As well, scar tissue is the primary site of infiltration as opposed to the regular inferior dermal depth. What was uncertain in these types of cases was: if PMMA can help correct the deformity and if so, will the correction last?
There was a greater resistance to the injection of PMMA directly into scar tissue when compared with injection into normal skin. In addition, to obtain an even natural feel and contour to the infiltrated area, a more aggressive and longer duration of manual massage of the tissue is required. The injections (ranging from $0.5 \mathrm{~mL}$ to $2.2 \mathrm{~mL}$ ) added needed volume and a natural contour to soft tissue facial abnormalities. Aside from the greater resistance to injection and the additional need for massage, the tissue fillant could be added with no significant procedure-related difficulties. In all three cases, PMMA infiltration improved the appearance of the defects in question. Subjectively, the patients' satisfaction ranged from moderate to high.

Because these patients received the PMMA product from 1.5 to four years ago, it was possible to evaluate long-term outcomes. With all three cases there were no cases of allergic reactions, granuloma formation, extrusion of the beads, or any form of short-and/or long-term adverse reaction. PMMA soft tissue infiltration has already been proven to produce longterm results in aesthetic patients, and its usefulness appears to cross over to these three reconstructive cases. There was no evidence of deterioration of the correction objectively and the patients maintained the same degree of satisfaction. 
As with the aesthetic use, knowing that the correction is in all likelihood permanent, it is better to err on the side of conservativeness and not over correct. Therefore, reconstructive surgeons are cautioned to use less than or equal to the volume of the PMMA product required, and to plan for a secondary procedure several months later if needed.

\section{CONCLUSION}

PMMA microsphere injection provided some improvement in the above facial reconstructive cases both objectively and with regards to patient satisfaction. Long-term results are the same. We therefore suggest that PMMA microspheres can be used as a reconstructive option for small soft tissue defects. It can be infiltrated directly into scar tissue with no significant increase in technical difficulty, producing adequate, longlasting results.

\section{REFERENCES}

1. Lemperle G, Hazan-Gauthier N, Lemperle M. PMMA microspheres (Artecoll) for skin and soft tissue augmentation:

Part II. Clinical investigations. Plast Reconstr Surg 1995;96:627-37.

2. Lemperle G, Ott H, Charrier U, Hecker J, Lemperle M. PMMA microspheres for intradermal implantation: Part I. Animal research. Ann Plast Surg 1991;26:57-63.

3. McClelland M, Egbert B, Hanko V, Berg RA, DeLustro F. Evaluation of artecoll polymethylmethacrylate implant for softtissue augmentation: Biocompatibility and chemical characterization. Plast Reconstr Surg 1997;100:1466-74.

4. Lemperle G, Kind P. Biocompatibility of Artecoll. Plast Reconstr Surg 1999;103:338-40.

5. Rudolph CM, Soyer HP, Schuller-Petrovic S, Kerl H. Foreign body granulomas due to injectable aesthetic microimplants. Am J Surg Pathol 1999;23:113-7.

6. Lemperle G, Gauthier-Hazan N, Lemperle M. PMMA microspheres (Artecoll) for long lasting correction of wrinkles: Part III.

Refinements and statistics. Aesthetic Plast Surg 1998;22:356-65. 